\title{
Recognition of States: International Law or Realpolitik? The Practice of Recognition in the Wake of Kosovo, South Ossetia, and Abkhazia
}

\author{
CEDRIC RYNGAERT AND SVEN SOBRIE*
}

\begin{abstract}
This article deals with the fundamental evolution that the process of state recognition has gone through during the past few decades. Whereas the recognition of new states used to be subject to a relatively concise and clear-cut normative framework consisting of factual criteria, the dissolution of Yugoslavia marked the introduction of a new set of moral norms used to determine whether or not an entity should be recognized as a state. This evolution gave rise to a high level of uncertainty, among both authors and the state community, as was painfully shown by the international discord during the crises in Kosovo and South Ossetia/Abkhazia. A renewed normative framework for recognition that integrates both factual and moral criteria is needed if the international community wants to prevent each claim to statehood becoming a threat to international stability.
\end{abstract}

\section{Key words}

Kosovo; recognition; self-determination; state discretion; statehood

\section{INTRODUCTION}

The body of international legal rules governing the process of state recognition finds itself in an existential crisis. Even though the applicability of a basic set of legal rules on the recognition of states remains the starting point of much legal scholarship, ${ }^{\mathrm{I}}$ the practice of the last few years seems to depict a different reality in which political convenience rather than legal norms plays the leading role.

Fundamental questions as to the role of law and politics in the recognition process were brought into particularly stark relief in the context of the international community's reactions to the dismemberment of Yugoslavia in the early I990s and the ensuing creation of new states. ${ }^{2}$ These reactions were

Cedric Ryngaert, Associate Professor of International Law, Utrecht University [C.M.J.Ryngaert@uu.nl]; Assistant Professor of International Law, Leuven University [Cedric.Ryngaert@law.kuleuven.be]; Sven Sobrie, Research Fellow, Department of Public Law, Leuven University [Sven.Sobrie@law.kuleuven.be].

I See, e.g., J. Crawford, The Creation of States in International Law (2006), v; R. Sloane, 'The Changing Face of Recognition in International Law: A Case Study of Tibet', (2002) I6 Emory ILR I07, at I I8.

2 R. Mullerson, International Law, Rights and Politics: Developments in Eastern Europe and the CIS (I994), I I9; see generally R. Rich, 'Recognition of States: The Collapse of Yugoslavia and the Soviet Union', (I993) 4 EJIL 36; and also R. Thomas, 'Self-Determination and International Recognition Policy: An Alternative Interpretation of Why Yugoslavia Disintegrated', (I997) I60 World Affairs I7. 
characterized by inconsistency, obscurity, and an apparently declining role for international law. ${ }^{3}$

But what started out as uncertainty culminated in mere disillusion in the aftermath of recent events in Kosovo, South Ossetia, and Abkhazia. ${ }^{4}$ While the International Court of Justice's Kosovo Advisory Opinion does not purport to take a position on issues of recognition (as these would fall outside the scope of the narrow question posed by the UN General Assembly), 5 its opinion that international law contains no prohibition on declarations of independence ${ }^{6}$ creates the impression that international law remains silent in the face of state creation and its consequences, including recognition.

Fatalism and a declining relevance for international law also beset other areas of international relations: most notably, the international legal norms on the use of force are under mounting pressure, since recent developments in Kosovo and Iraq seem to have relegated the applicable rules to the realm of irrelevance in favour of a pure balance-of-power approach. ${ }^{7}$ A critical reflection on the role of these legal norms and their distorted relation to political discretion forces itself upon legal scholars, in order to prevent the demotion of international law to a reservoir of arguments used to back up decisions based on purely political considerations.

As far as the use of force goes, there have already been some laudable attempts to regain legal ground from political discretion. ${ }^{8}$ This article has the same goal concerning the legal rules governing recognition. It aims to analyse the current state practice and the way law and politics determine the process of state recognition, in order to shed light on how legal norms should be conceived to restore confidence in international law. That such a reflection is far from an abstract academic pastime is shown by the widely felt need to bring back some consistency in the practice of state recognition. ${ }^{9}$ The current perception of unrestrained political arbitrariness leads to uncertainty and unrest, which threaten to undermine international stability. ${ }^{\text {IO }}$ An international legal framework, adjusted to recent evolutions and practices, is the best way to counter this threat.

3 D. Raic, Statehood and the Law of Self-Determination (2002), especially at 3: '[I]t has been suggested that the recognition of the new States which were formed within the boundaries of the former Yugoslavia and the former Soviet Union must mainly be explained in terms of politics. In other words, the creation and recognition of these new States should be seen to have taken place mainly outside the domain of international law.'

4 J.Almqvist, 'The Politics of Recognition, Kosovo and International Law' (working paper), (2009), Real Instituto Elcano, at 2: '[I]n the case of Kosovo at least, and until now, it may well be asserted that international law has failed, in a rather blunt way, to offer something like a common framework with the capacity of constraining the range of reactions of third states.'

5 Accordance with International Law of the Unilateral Declaration of Independence in Respect of Kosovo, Advisory Opinion of 22 July 2010, [2010] ICJ Rep. (Kosovo Advisory Opinion), para. 5I (in which the Court noted that the question posed did not 'ask about the validity or legal effects of the recognition of Kosovo by those States which have recognized it as an independent State'). Decision available at www.icj-cij.org/docket/files/I4I/I5987.pdf.

6 Ibid., para. 79.

7 H. Köchler (ed.), The Use of Force in International Relations: Challenges to Collective Security (2006), I6.

8 Ibid.; see also T. Gazzini, The Changing Rules on the Use of Force in International Law (2005), 266.

9 Rich, supra note 2, at 64; C. Levine, 'The Legacy of Humpty Dumpty: The Role of Recognition in the Dissolution of Yugoslavia', in M. Spencer (ed.), The Lessons of Yugoslavia (2000), I40.

Io S. Mahmoudi, 'Recognition of States: The Case of Former Yugoslav Republics', in O. Bring and S. Mahmoudi (eds.), Current International Law Issues: Nordic Perspectives (I 994), I 58. 
The article starts out by discussing the concept of recognition from the angle of the constitutive and declaratory schools (section 2) and subsequently provides an overview of the traditional normative framework governing recognition, based on the 'Montevideo' factual criteria for statehood and the prohibition of recognizing entities that have come into being through a violation of jus cogens (section 3). As will be set out in section 4, this traditional framework was challenged during the Yugoslavia crisis. New recognition criteria, imbued with a measure of morality, saw the light, although practice was inconsistent. Inconsistency and politicization also remain prevalent after Yugoslavia, however, as recent recognition practice regarding Kosovo, South Ossetia, and Abkhazia testifies (section 5). In the final section, modest proposals are formulated to restore the balance between law and politics in international recognition law and practice.

\section{RECOGNITION: THEORY AND PRACTICE}

Before exploring the balance between law and politics in the process of state recognition, it might be useful to look more closely into the meaning of 'state recognition'. The search for a definition gets bogged down almost immediately in a long-running debate that deeply divides the international legal scene: is recognition an essential requirement for statehood - the constitutive school - or rather a confirmation of a pre-existing factual situation - the declaratory school? Even though an exhaustive examination of this issue falls outside the scope of this article and, in fact, does not lead to satisfactory results, it may nevertheless be useful to revisit the basic arguments of each school.

According to the constitutive theory, an entity becomes a state only when it is recognized as such. Recognition is therefore a conditio sine qua non for statehood. ${ }^{\text {I }}$ This theory is supported by the traditional positivist conception of international law as a consensual jus gentium voluntarium: an entity can only develop into a state with the agreement of other states. ${ }^{{ }^{2}}$ As a practical side effect, the difficult and complex question of statehood is reduced to the more pragmatic question of whether the entity has been recognized by other states. ${ }^{13}$ As is well known, the constitutive theory has some serious drawbacks, especially when an entity has been recognized only by part of the community of states. At a very concrete level, questions arise as to how many recognizing states are needed before an entity 'transforms' into a state and whether the decision to recognize should be based on facts, norms, geopolitical considerations, or a combination of factors. At a more fundamental level, the theory leads to the somewhat counterintuitive conclusion that statehood is a relative, rather than an absolute, concept. ${ }^{\mathrm{I}}$

I I J. Dugard and D. Raic, 'The Role of Recognition in the Law and Practice of Secession', in M. Kohen (ed.), Secession: International Law Perspectives (2006), 97.

I 2 P. Menon, The Law of Recognition in International Law: Basic Principles (1994), 8; T. Grant, The Recognition of States: Law and Practice in Debate and Evolution (I999), 97.

I3 Sloane, supra note I, at II6-I7.

I4 Crawford, supra note I, at 2I; K. Marek, Identity and Continuity of States in Public International Law (I968), I32. 
According to the declaratory school, then, statehood is fully determined by a set of factual conditions, being a permanent population, a fixed territory, a government, and the ability to enter into relations with other states. ${ }^{15}$ These criteria, which are commonly accepted to be customary international law, are listed in the Montevideo Convention on Rights and Duties of States and are further elaborated in doctrine and jurisprudence. ${ }^{16}$ Once an entity fulfils these criteria, it is a state erga omnes. Recognition is, in this theory, nothing more than an official confirmation of a factual situation - a retroactive act that traces back to the moment at which the factual criteria were fulfilled and the entity became a state. ${ }^{17}$ A formal recognition admittedly has some practical consequences as to the relations between the recognizing and the recognized state, yet it is not a necessary element of statehood.

In current doctrine and jurisprudence, the declaratory theory is the dominant theory. ${ }^{18}$ An important aspect of its success lies in the fact that it deprives states of the prerogative of deciding on statehood based on political arbitrariness, in favour of objective legal norms. ${ }^{\text {I9 }}$ And yet, this theory has its own discontents. First of all, it is often pointed out that non-recognized entities have no international legal personality and thus cannot be considered to be a state, even if they meet all the requirements outlined above. ${ }^{20}$ Another problem is that the theory does not look at the way the entity has acquired the necessary requirements, as a result of which states can come into being through grave violations of international law. ${ }^{2 \mathrm{I}}$ State practice responds to such events by not granting recognition to these entities - a sanction that cannot be fitted into the pure declaratory theory. ${ }^{22}$ More fundamentally, the problem seems to be reducible to the basic declaratory assumption that an entity can have the legal qualification 'state' as such. This idea of 'statehood as a fact' seems to confuse facts with law - ex factis jus non oritur. ${ }^{23}$

The wide gap between the constitutive theory - in which recognition is fully normative - and its declaratory counterpart - in which recognition has no normative value at all - seems unbridgeable. ${ }^{24}$ Some authors propose a 'third way' to bridge

I5 Sloane, supra note I, at II5.

I6 Art. I, I933 Montevideo Convention on Rights and Duties of States, I65 LNTS I 9; see further the discussion in section 3.I, infra.

I7 Raic, supra note 3, at 32.

I8 Crawford, supranote I, at 23; Deutsche Continental Gas Gesellschaft v. Polish State, Germano-Polish Mixed Arbitral Tribunal, Decision of I August I929, (1929) AD 5, at I3; Arbitration Commission of the Peace Conference on the Former Yugoslavia (Badinter Commission), Opinion No. I, 29 November I99I, (I992) 3 EJIL I, at I82; Badinter Commission, Opinion No. I0, 4 July I992, (I993) 4 EJIL I, at 90.

I9 B. Roth, Governmental Illegitimacy in International Law (I999), I28.

20 G. Kreijen, State Failure, Sovereignty and Effectiveness: Legal Lessons from the Decolonization of Sub-Saharan Africa (2004), I6.

2 I Raic, supra note 3, at I25.

22 R. Caplan, Europe and the Recognition of New States in Yugoslavia(2007), 57; Kreijen, supra note 20, at I 8. Compare this practice with the analysis of the ICJ in the Kosovo Advisory Opinion, para. 8I: the Court notes that in all of those instances of the Security Council's making a determination as to the illegality of a declaration of independence, 'the illegality attached to the declarations of independence ... stemmed not from the unilateral character of these declarations as such, but from the fact that they were, or would have been, connected with the unlawful use of force or other egregious violations of norms of general international law, in particular those of a peremptory character (jus cogens)'.

23 Crawford, supra note $\mathrm{I}$, at 5.

24 Marek, supra note I4, at I39; Crawford, supra note I, at 27. 
this gap, in which recognition is neither merely constitutive nor merely declaratory. In this view, statehood is seen in terms of effectiveness, with recognition as a political act that strengthens the international effectiveness of an entity. As such, recognition is both constitutive - since it creates stately relations between the recognizing and the recognized state - and declaratory - since it does not, by itself, bestow statehood on the entity. ${ }^{25}$ However, instead of attempting to find a solution to this deadlock, one could question the practical relevance of this theoretical debate. Modern state practice indeed offers a plethora of 'hard cases' that, in their entirety, cannot be fitted into either one of the legal theories, but are somehow accommodated by the international legal order. Israel offers an excellent example: it has all attributes of statehood, yet it is not recognized as a state by some Arabic states. These states, however, have held Israel responsible for violations of international law. Such a practice, in which recognition is said to be normative without, however, blocking legal personality, cannot be explained fully by either the constitutive or the declaratory theory. ${ }^{26}$

This is not to say that state practice should be the only norm when dealing with issues such as state recognition. International law is built upon the delicate balancing act between holding onto normative principles, embedded in theoretical frameworks - without which international law would lose its status as 'law' and adapting to ever-changing state practice - without which international law would lose its effectiveness and, eventually, its legitimacy. ${ }^{27}$ This is all the more true when it comes to state recognition, where political state practice and normative international law inevitably blend together. ${ }^{28}$

The starting point of this article is the impression that this necessary balance between law and politics in the process of state recognition has been upset. Recent developments in Yugoslavia, Kosovo, and Georgia have put an end to a period during which state practice on recognition was relatively consistent. As a direct consequence, there is a growing uncertainty as to which norms regulate state recognition nowadays. ${ }^{29}$ If international law wants to maintain its credibility and its role as a stabilizer of international relations, it needs to adapt itself to these recent

25 See J. Verhoeven, La reconnaissance internationale dans la pratique contemporaine (I975), 679; J. d'Aspremont, 'Regulating Statehood: The Kosovo Status Settlement', (2007) 20 LJIL 649, at 655.

26 For criticism of the theoretical approaches, see, e.g., Roth, supra note I9, at I 29: 'Even declaratists are bound to concede that entities are assured of enjoying rights under international law only after recognition, just as constitutivists concede that once recognized, the entity's status is retroactive to the point at which the factual circumstances justified the claim to the status. What is important is that international law operates to protect the interests of an entity only once the entity gains widespread legal (as opposed to political) recognition by other states. In that sense, recognition is clearly constitutive; beyond that, the debate begins to resemble a discussion of metaphysics.' See also I. Brownlie, 'Recognition in Theory and Practice', in R. MacDonald and D. Johnston (eds.), The Structure and Process of International Law: Essays in Legal Philosophy, Doctrine and Theory (I986), 634: 'In the literature the theories have tended to stand in front of the issues and to have assumed a "theological" role as a body of thought with its own validity which tends to distract the student, and to play the role of master rather than servant.'

27 H. Lauterpacht, Recognition in International Law (I947), 427.

28 L. Hammer, A Foucauldian Approach to International Law: Descriptive Thoughts for Normative Issues (2007), 29; Almqvist, supra note 4, at 6; H. Lauterpacht, 'Recognition of States', in E. Lauterpacht (ed.), International Law, Being the Collected Papers of Hersch Lauterpacht, Vol. I (I970), 320.

Rich, supra note 2 , at 37. 
developments, without, however, abandoning its normative aspirations. ${ }^{30}$ Before looking ahead at a renewed international framework, it might be useful to first take a closer look at the traditional legal setting that still, at least in theory, governs the process of state recognition.

\section{THE TRADITIONAL NORMATIVE FRAMEWORK}

When looking at the classical legal setting that regulated, or at least tried to regulate, the process of state recognition, one can see a fairly economical two-pillar framework, consisting of the Montevideo requirements on the one hand and the non-violation of jus cogens norms on the other. ${ }^{3 \mathrm{I}}$

The best-known and most cited legal document on state recognition is undoubtedly the Montevideo Convention on Rights and Duties of States. Article I reads as follows: 'The state as a person of international law should possess the following qualifications: a) a permanent population; b) a defined territory; c) government; and d) capacity to enter into relations with the other states. ${ }^{32}$

If an entity is recognized as a state while not meeting these criteria, the premature recognition is seen as a violation of the principle of non-intervention and therefore an illegitimate act. ${ }^{33}$

A striking characteristic of the Montevideo requirements is the central role of the principle of effectiveness: an entity is a state only when certain factual conditions are met - a purely empirical check. ${ }^{34}$ This can be explained by the horizontal character of the state community: lacking a central organ that can bestow and withdraw rights and duties that come with being a state, those legal consequences are often created by the sheer effectualization of a claim. ${ }^{35}$ Granting fait accomplis a legal base furthermore contributes to the stability of the international legal order. Of course, this brings us back to the inevitable tension between normativity and pragmatism that was briefly touched upon in the previous section.

Doctrine and jurisprudence have elaborated on the concise requirements in great detail and it would be beyond the scope of this article to delve deeper into the matter. After all, it is not so much the interpretation of the criteria that is important, but the mere fact that the criteria have been accepted as the normative starting point on state recognition, not only by legal scholars and lawyers, but also, and more importantly, by states. ${ }^{36}$ One can remark that these criteria, whether laid

Crawford, supra note I, at 98; A. Hurell, 'Conclusion: International Law and the Changing Constitution of International Society', in M. Byers (ed.), The Role of Law in International Politics: Essays in International Relations and International Law (I999), 33 I.

3I Caplan, supra note 22, at 55.

32 Art. I, I933 Montevideo Convention on Rights and Duties of States, I65 LNTS I 9.

33 Raic, supra note 3, at 82.

34 Crawford, supra note I, at 46; Kreijen, supra note 20, at Io9.

35 Raic, supra note 3, at 5I.

36 The US State Department, for example, declared in I 976 that the USA would decide on matters of recognition based on the establishment of certain facts, including 'effective control over a clearly-defined territory and population; an organized governmental administration of that territory; and a capacity to act effectively to conduct foreign relations and to fulfil international obligations'. See. E. McDowell, 'Contemporary Practice of the United States Relating to International Law', (I977) 7 I AJIL 337. See also, in relation to Canada, 
down in formal policy rules or not, leave substantial room for interpretation, as a result of which states, at the end, reserve a lot of discretionary manoeuvring space for themselves. This elasticity does not, however, alter the fundamental fact that states consider themselves bound by these criteria and use them to account for their recognition practice. The Montevideo requirements therefore constitute a first normative pillar on which state practice has rested for the past few decennia. The second pillar is much more recent and relates to violations of jus cogens.

The prohibition of recognizing entities as states when they have come into being through violation of a jus cogens norm originates from the non-recognition of Manchukuo by the United States in I93I. This refusal to recognize that Japanese satellite state in what is now the People's Republic of China led to the so-called Stimson doctrine, which was later taken over by the League of Nations and its successor, the United Nations, to become a universal norm that seriously limits state discretion in the process of state recognition. ${ }^{37}$ The fact that this duty of non-recognition now has universal validity is highlighted by its insertion in Article 4I(2) of the Articles on the Responsibility of States for Internationally Wrongful Acts: 'No State shall recognize as lawful a situation created by a serious breach [of an obligation arising under a peremptory norm of general international law], nor render aid or assistance in maintaining that situation. 38

One should note the fundamental difference from the Montevideo requirements: whereas the latter base recognition in essence on the effectiveness of an entity, the duty of non-recognition envisages the nullity of the consequences that a grave violation of international law might have regardless of the effectiveness of the entity emerging from such a violation. ${ }^{39}$

The traditional legal framework governing state recognition appeared to be clear and concise, and thus led to a relatively consistent state practice. ${ }^{40}$ Since international law contained no obligation to recognize an entity when it met all criteria,

J. Beesley and C. Bourne (eds.), 'Canadian Practice in International Law during I 97 I as Reflected Mainly in Public Correspondence and Statements of the Department of External Affairs', (I972) Io CYIL 287, at 308-9. On a similar note, the British Foreign Office justified the non-recognition of Bophuthatswana as follows: 'The normal criteria which the Government apply for recognition of a state are that it should have, and seem likely to continue to have, a clearly defined territory with a population, a Government who are able of themselves to exercise effective control of that territory, and independence in their external relations'; see G. Marston (ed.), 'United Kingdom Materials on International Law', (I986) 57 BYIL 507.

37 V. Gowlland-Debbas, Collective Responses to Illegal Acts in International Law: United Nations Action in the Question of Southern Rhodesia (I990), 282. It is noted that this refusal was not based on the violation of a universal norm, but on the infringement of a treaty. This limited the scope of the newly created practice. However, this code of conduct (duty of non-recognition) gradually evolved into a collective and effective international legal rule as a result of its linkage to jus cogens as a nucleus of elementary legal norms that are universally binding merely by their fundamental nature; cf. J. Dugard, 'Recognition and the United Nations', in International Law Commission, Hersch Lauterpacht Memorial Lectures (I987), I33, at I37-47.

38 This wording also shows that the scope of the obligation is not limited to non-recognition of states: it also includes other acts such as unlawful territorial expansions and occupations. Cf. Dugard, supra note 37, at I35. Obviously, the question immediately arises as to what norms can be regarded as of such importance as to constitute jus cogens. While an in-depth examination of this issue falls outside the scope of this article, the following norms could arguably be so considered: the prohibition of aggression, the prohibition of acquisition of territory by force, the prohibition of racial discrimination and apartheid, and the right to self-determination.

39 V. Gowlland-Debbas, 'The Functions of the UN Security Council in the International Legal System', in Byers, supra note 30 , at 280 .

40 Mahmoudi, supra note Io, at I37; Rich, supra note 2, at 36. 
but only a negative duty not to recognize when not all criteria were met, the applicable legal rules could be described as an outer limit on state discretion. ${ }^{4 \mathrm{I}}$ A concise yet clear normative framework, with a consistent state practice as its corollary, thus added to a stable international order, in which dubious claims were faced with rejection and straightforward criteria prevented a pandemic of seceding entities claiming statehood..$^{2}$

The dissolution of Yugoslavia, however, marked the beginning of a fundamental evolution within international law in general and state recognition in particular, the results of which are still not fully crystallized - witness recent developments in Kosovo and Georgia. This diverging state practice, together with the underlying reasons and the consequences for the normative framework and for the fragile balance between law and politics, will be discussed below.

\section{YugOSLAVIA: A NEW LEGAL FRAMEWORK IN THEORY AND PRACTICE}

The chain of events that threw the Balkans into turmoil in the early I99os constituted, in retrospect, a catalyst for fundamental changes in international law. The nationalistic tensions that had mounted steadily since Tito's death in I980 were putting the federal constellation of the Socialist Federal Republic of Yugoslavia under severe pressure, leading to outbursts of violence and growing calls for independence, most notably in Croatia and Slovenia. During this process of increasing tension, the international community stood on the sideline, too occupied by events in the Gulf and the implosion of the USSR to meddle in what seemed to be a domestic quarrel. The few statements that were made on the issue excelled in ambiguity, for, even though both the United States and the European Community subscribed to the territorial integrity of Yugoslavia and rejected any form of secession, they also made clear that there would be no external intervention when secession took place. ${ }^{43}$ This half-hearted attitude only accelerated the process of dissolution: on 25 June I99I, both Slovenia and Croatia declared independence, thereby not only starting a bloody civil war that only lasted for Io days in Slovenia, but dragged on until January I 992 in Croatia, but also opening Pandora's box in the region, since, within a time frame of months, a multitude of other entities declared independence, including Bosnia and Herzegovina, Macedonia, Serbian Krajina, Republika Srpska, and Western Bosnia. The laws on state recognition were suddenly facing an enormous challenge.

\section{I. New norms}

It was the European Community that, by tacit agreement, took the lead in dealing with the crisis that was occurring in its own back garden. ${ }^{44} \mathrm{~A}$ first delicate issue that needed to be dealt with swiftly was the stand to be taken concerning the recognition

\footnotetext{
4I Raic, supra note 3, at 9I.

42 J. Wouters, B. De Meester, and C. Ryngaert, 'Democracy and International Law', (2003) 34 NYIL I39, at I56; Caplan, supra note 22, at 9.

43 P. Radan, The Break-Up of Yugoslavia and International Law (2002), I6o.

44 Levine, supra note 9, at I28.
} 
of the new republics - a matter on which Europe quickly proved to be deeply divided. France, amongst others, supported a federal Yugoslavia, whereas the likes of Germany and Belgium wanted to leave the door open to recognition of Slovenia and Croatia. ${ }^{45}$

The European Community, however, assisted by the EC Arbitration Commission on Yugoslavia ('the Badinter Commission'), which dealt with legal issues such as sovereignty, state recognition, the right to self-determination, and state succession, issued rather swiftly a Declaration on the Guidelines on the Recognition of New States in Eastern Europe and in the Soviet Union, on 23 December I99r. This declaration listed the conditions that entities had to fulfil before they could be recognized. As such, it provided the normative ground for European state practice vis-à-vis the new Balkan republics. ${ }^{4}$

The differences from the traditional framework were striking. The right to selfdetermination was mentioned as an important principle that would be taken into consideration by the European Community and its member states in their recognition practice, even though that right was traditionally confined to colonial contexts. Another remarkable condition mentioned was the democratic commitment that the new entities had to show before recognition could be granted. The traditional legal framework had never concerned itself with the internal organization of a would-be state, as this would have been considered an unlawful interference in this state's internal affairs. The absence of democratic governance therefore never stood in the way of recognizing a state - witness the universal recognition of new and often farfrom-democratically-organized states during and after the wave of decolonization. ${ }^{47}$ The EC guidelines, however, explicitly required the new republics to 'constitute themselves on a democratic basis', in the same breath demanding respect for human rights and minority rights as well - a remarkable addition to the traditional framework that confined itself to racial discrimination and apartheid. Finally, note should be taken of the required commitments with regard to disarmament and nuclear non-proliferation.

At first sight, these new criteria show international law gaining ground on political discretion in the process of state recognition, since the fairly concise body of rules on state recognition seems to be extended with an impressive list of new, farreaching criteria. ${ }^{8}$ What remained unchanged was the function of international law as the outer limit on state discretion. ${ }^{49}$ That said, although the European Council, supported by the Badinter Commission, did its best to create a sound, exhaustive, and coherent normative system with regard to recognition of the new republics, state practice quickly proved to be not very strict in adhering to this framework.

Radan, supra note 43 , at $\mathrm{I} 62$.

46 EC Declaration on the 'Guidelines on the Recognition of New States in Eastern Europe and in the Soviet Union’, i6 December I991, (I993) 4 EJIL 72.

47 Wouters, De Meester, and Ryngaert, supra note 42, at 157.

48 W. Grewe, The Epochs of International Law (2000), 7 Io.

49 According to the Badinter Commission, recognition 'was a discretionary act which other States were entitled to perform when they chose and in a manner of their choosing, subject only to compliance with the imperatives of public international law'; see Badinter Commission, Opinion No. IO, 4 July I992, (I993) 4 EJIL 90 , at 90. 


\subsection{The new law on recognition brought into practice}

On I 5 January I992, the European Community, positively advised by the Badinter Commission, decided to recognize Slovenia and Croatia as new, independent states. In so doing, it made clear that the promising new criteria could indeed be applied in a very flexible way.

Croatia, for its part, did not have a stable government able to control the whole of its territory at that time..$^{50}$ The decision to grant recognition therefore explicitly deviated from an essential traditional requirement. In addition, that same decision to recognize Croatia departed from one of the newly created norms as well, since the Badinter Commission had noted that the Croatian constitution did not fully meet the requirements on minority protection. ${ }^{5 \mathrm{I}}$ The recognition of Bosnia and Herzegovina on 7 April I992 shows the same free interpretation of the legal framework on state recognition. Bosnia and Herzegovina did not have an effective government able to control even a substantial part of its territory - something even its president had to admit by stating that his country could not protect its independence without foreign military aid..$^{2}$ The bloody civil war that had resulted from this state of affairs furthermore did not provide an environment in which human rights were adequately protected. ${ }^{53}$

Whereas two of the three recognized republics did not fully meet the normative framework, either the traditional or the new one, Macedonia became the victim of an opposite phenomenon: even though the entity fulfilled all possible criteria, it was initially only recognized by a handful of states. ${ }^{54}$ Although the Badinter Commission had given positive advice on the matter, recognition was vetoed by Greece - a deadlock that was only broken in I993.55

Interestingly, non-European states responded quite differently to the events in the Balkans in terms of recognition. The United States felt no need whatsoever to justify

50 One-third of that territory was being occupied by Croatian Serbs who declared their own Republic of Serbian Krajina in these regions, which had triggered a bloody civil war; cf. T. Musgrave, Self-Determination and National Minorities (I997), 206.

5I Badinter Commission, Opinion No.5, I I January I992, (I993) 4 EJIL 76; the EC, however, deemed a declaration of Croatian president Tudjman, in which he guaranteed that this gap would be filled, sufficient - from a legal perspective, a very dubious procedure indeed: cf. Raic, supra note 3, at 432-3.

52 Rich, supra note 2, at 5I. More than two-thirds of the Bosnian territory was being controlled by rebellious Bosnian Serbs, who had declared their own Serbian Republic of Bosnia and Herzegovina a few months earlier; cf. Musgrave, supra note 50, at 206.

53 J. Dugard, International Law: A South African Perspective (2005), 90.

54 Radan, supra note 43, at I94-5.

55 Greece rejected the use of the name 'Macedonia' and other Hellenistic symbols mainly for fear of possible future territorial claims of its new neighbour; cf. S. Murphy, 'Democratic Legitimacy and the Recognition of States and Governments', in G. Fox and B. Roth (eds.), Democratic Governance and International Law (2000), I35; N. Gianaris, Geopolitical and Economical Changes in the Balkan Countries (I996), I52. This deadlock was only broken in I993, when the new republic was accepted as a member of the UN under the provisional name of the 'Former Yugoslav Republic of Macedonia'; cf. Radan, supra note 43, at I95. During the following months, all European member states recognized the republic under the same name - save for Greece, which only recognized the entity as a state in September I 995 . The issue is still not entirely settled, though - witness the case that the FYROM brought against Greece before the ICJ, on the grounds that the latter would unlawfully have opposed the former's entry to NATO: Application of the Interim Accord of I3 September I995 (The Former Yugoslav Republic of Macedonia v. Greece) (see www.icj-cij.org for the current status of the case). 
its policy of recognizing the former Yugoslav republics within a broader normative framework. ${ }^{56}$

The same holds true for other Western states such as Australia and Canada. ${ }^{57}$ It was therefore mainly because of the European Community's actions that the international rules on state recognition evolved during the Yugoslav crisis. This evolution led to a somewhat paradoxical situation. On the one hand, the set of rules governing state recognition appeared to be considerably extended. On the other, however, the rules were not applied in a very consistent manner. This paradox cast a shadow over the binding character of these rules and over how the international law on recognition was to develop further.

\subsection{International law on state recognition: fundamental uncertainty}

In the aftermath of Yugoslavia's dissolution, a fierce debate has erupted over the effect of the European Community's recognition policy on the crisis in the Balkans. ${ }^{8}$ One glance at legal doctrine on the matter shows that the sudden creation of a completely new normative framework, together with the way in which state practice has interpreted these norms, has created a lot of confusion. A first source of uncertainty is the concrete content of the new criteria, particularly of the right to self-determination. While state practice in Yugoslavia has shown that this right is no longer confined to colonial situations, the new scope remains very unclear. ${ }^{59}$ And, unfortunately, the International Court of Justice has not provided any guidance on the matter in its Kosovo opinion.

A second point of confusion that has arisen is the relationship between the new requirements and the traditional criteria. More specifically, the state practice mentioned above raises the question of the relevance of the Montevideo requirements as a limit on state discretion. ${ }^{60}$ Have the new criteria replaced the traditional requirements ${ }^{65}$ Or do the new criteria merely add to the traditional framework instead of replacing it? ? $^{62}$

56 Cf. President Bush's statement on the recognition of Bosnia and Herzegovina, Croatia and Slovenia, 7 April I992, in S. Trifunovska (ed.), Yugoslavia through Documents: From Its Creation to Its Dissolution (I994), 52 I: 'The United States recognizes Bosnia and Herzegovina, Croatia and Slovenia as sovereign and independent states ... We take this step because we are satisfied that these states meet the requisite criteria for recognition.'

57 N. Gammer, From Peacekeeping to Peacemaking: Canada's Response to the Yugoslav Crisis (200I), I 26; D. Markusic, 'The Rocky Road to International Recognition', (r993) 30 Political Thought: Croatian Political Science Review I9, at 25 .

58 S. Lucarelli, Europe and the Breakup of Yugoslavia: A Political Failure in Search of a Scholarly Explanation (2000), 278; Thomas, supra note 2, at I 7 .

59 Cf. D. Wippman, 'Introduction: Ethnic Claims and International Law', in D. Wippman (ed.), International Law and Ethnic Conflict (I998), I 2: 'In practice, the international community has yet to settle on any single version of self-determination. ... The normative confusion generated by this state of affairs is evident in the divergent invocations of self-determination in the context of the breakup of the Socialist Federal Republic of Yugoslavia'; see also J. Duursma, Fragmentation and the International Relations of Micro-States: Self-Determination and Statehood (I996), 72.

60 Rich, supra note $2,56$.

6 I Ibid., at 43 (referring to the recognition of Croatia and Bosnia and Herzegovina to back their claim, since neither of those entities passed the Montevideo test at the moment of their recognition).

62 Musgrave, supra note 50, at 204; J. Vidmar, 'International Legal Responses to Kosovo's Declaration of Independence', (2009) 42 Vand. JTL 779, at 84I (finding support in the aforementioned EC Declaration that explicitly mentions 'the normal standards of international practice' as a factor taken into account when assessing a claim to statehood). 
A third and final issue touches upon the very foundations of international law and its uneasy relation to political discretion: to what extent can the criteria for state recognition still be considered to be normative rules, when, apparently, these criteria can be readily set aside for the entity that should or should not be recognized, depending on the political situation? Therefore, it may seem that the new rules that the European Community has created are mainly, or even entirely, political criteria, notwithstanding the legal discourse and the interventions of the Badinter Commission. ${ }^{63}$ Especially the requirements of human-rights protection and democracy are considered to be political guidelines more than anything else, and the recognition of Croatia and of Bosnia and Herzegovina is often brought forward as an argument in support of this interpretation. ${ }^{64}$ Another line of reasoning is based on the EC Declaration itself, where 'the political realities in each case' are mentioned as a factor to be taken into account. ${ }^{65}$

Accordingly, there is little doubt that, as a result of the striking discrepancy between the objectivity of the norms on the one hand and the inconsistency of state practice on the other, the dissolution of Yugoslavia created a lot of uncertainty and confusion as to the set of norms governing state recognition. ${ }^{66}$ The outcome of this evolution remained highly uncertain in the years following Yugoslavia's dissolution and it remained to be seen whether and how subsequent state practice would clear things up.

\section{State Practice after Yugoslavia: Kosovo, SOUTH Ossetia, AND ABKHAZIA ${ }^{67}$}

When Kosovo declared its independence from Serbia on I 7 February 2008, it marked the beginning of a year in which the international community would find itself faced with a series of very delicate cases with regard to state recognition. These events

63 Other authors, however, are more nuanced in their analysis of state practice, still seeing a role for international law. J. Charpentier, 'Les déclarations des douze sur la reconnaissance des nouveaux etats', (I992) 96 RGDIP 343, at 347: 'Il n'était pas inconcevable que les Douze conferent au résultat de leur concertation une valeur juridique obligatoire. Les deux déclarations auraient été alors des accords en forme simplifiée. Mais en réalité, les engagements souscrits ne dépassent pas la portée d'engagements politiques c'est-à-dire d'engagements qui, tout en étant destinés à orienter le comportement des Etats dans le sens indiqué, ne sauraient les y contraindre'; see also M. Weller, 'The International Response to the Dissolution of the Socialist Federal Republic of Yugoslavia', (I992) 86 AJIL 569, at 588.

64 C. Chinkin, 'International Law and Human Rights', in T. Evans (ed.), Human Rights 50 Years On: A Reappraisal (I998), I07; Dugard, supra note 53, at 90; Wouters, De Meester, and Ryngaert, supra note 42, at I 58-9.

65 See B. Boczek, International Law: A Dictionary (2005), Ioo: 'At least some of the criteria articulated by the EC in its Guidelines for recognition of the states emerging from the break-up of the Soviet Union and the SFRY were purely political conditions transcending the traditional qualifications for statehood required by international law. However, it appears that the standards devised by the EC, especially those pertaining to democracy, human rights, and treatment of minorities, have been rapidly evolving into legal criteria acquiring the nature of general standards of international law used in the recognition of states and governments.'

66 See also Mullerson, supra note 2, at I I 7: 'The emergence of new states in Eastern Europe and the former Soviet Union has raised issues relating to the recognition of states and has once more engendered discussions on whether such recognition is a political or legal phenomenon or whether it has a declaratory or constitutive nature.'

67 This article does not purport to be an exhaustive essay on contemporary recognition cases. Rather, it intends to analyse the relation between law and politics in the process of state recognition and the way in which states deal with this tension, by taking a closer look at some - though not all - recent recognition situations. 
also provided an opportunity for state practice to bring some sort of order out of the chaos in which the norms on state recognition had found themselves since the dissolution of Yugoslavia, almost 20 years earlier.

\subsection{Kosovo}

As is well known, Kosovo unilaterally declared its independence from Serbia on I7 February 2008. This caused the UN General Assembly, at the behest of Serbia, to request the International Court of Justice to give an advisory opinion on the legality of this declaration under international law. Controversially, in its 22 June 20 Io opinion, the International Court of Justice held this declaration to be not incompatible with UN Security Council Resolution I244 (I999), which established the UN Mission in Kosovo, with the Constitutional Framework for Kosovo (200I), or with general international law. But, more importantly for our purposes, the International Court of Justice kept silent about the consequences of the declaration of independence, including on the recognition of Kosovo. In fact, it is not impossible that the declaration itself is lawful (which it was, according to the Court), while the recognition of Kosovo as a state is unlawful. Indeed, with respect to Kosovo's purported right to secession, the Court stated that it is entirely possible for a particular act - such as a unilateral declaration of independence - not to be in violation of international law without necessarily constituting the exercise of a right conferred by it'. ${ }^{68}$ In any event, under the traditional model, as discussed above, international law only prohibits recognition as lawful of a situation created by a serious breach of an obligation arising under a peremptory norm of general international law. ${ }^{69}$ It is open to doubt whether a secession amounts to a serious breach of norms of jus cogens. In fact, if one reads the International Court of Justice's Kosovo Opinion carefully, it is even open to doubt whether a secession is a breach of international law in the first place. According to the Court, 'the scope of the principle of territorial integrity is confined to the sphere of relations between States' ${ }^{70}$ This seems to imply that a unilateral secession, which belongs to the sphere of intra-state relations (a sub-state entity separating from the mother state), does not violate the principle of territorial integrity. Either way, recognition of Kosovo would not be unlawful under international law, except, of course, if one believes that the presumably illegal use of force by NATO against Serbia in I999, which led to the creation of a UN transitional administration and ultimately to the independence of Kosovo, has a bearing on the argument: such use of force might violate a norm of jus cogens and, arguendo, prohibit states from recognizing the ensuing situation, namely Kosovo's statehood.

In practical terms, however, the law has taken a back seat in the process of recognizing Kosovo. To be true, upon learning of Kosovo's declaration of independence, the EC Council has noted 'that Member States will decide, in accordance with

68 Kosovo Advisory Opinion, para. 56.

69 Art. 4I, ILC Articles on the Responsibility of States for Internationally Wrongful Acts, (200I) YILC. See also Y. Ronen, Transition from Illegal Regimes in International Law (forthcoming 20I I).

70 Kosovo Advisory Opinion, para. 80. 
national practice and international law, on their relations with Kosovo'. ${ }^{7 \mathrm{I}}$ In reality, 'national practice' - this is diplomatic parlance for political expediency - has sidelined the role of international law in the recognition process. This made a uniform EC recognition practice a non-starter. An exhaustive and elaborate normative framework, as used by the European Community to deal with the dissolution of Yugoslavia a decade ago, was nowhere to be seen.

When browsing through the international reactions to Kosovo's declaration of independence, both European and non-European, the scarcity of references to international law is striking. References are often limited to a mere mentioning of 'international law', 'the rule of law', or a vague reference to the right to self-determination or the protection of minorities. ${ }^{72}$ States that recognized Kosovo have almost invariably justified their decision to grant recognition - if such a justification was given at all - by referring to political considerations, most notably the need for stability, peace, and security in the region, and the positive effect recognition would have on these parameters. ${ }^{73}$

Conspicuously, however, states that refused to grant recognition relied to a much greater extent, and in much greater detail, on international law in their line of reasoning. More specifically, the notions of state sovereignty and territorial integrity core principles of the Westphalian legal order - were often mentioned as reasons not to recognize Kosovo. ${ }^{74}$ Nonetheless, international law quite probably does not prohibit the recognition of a secession, since a secession does not rise to the level of a violation of a peremptory norm of international law. Therefore, the main reason for non-recognition is not so much situated in the sphere of international law as in the sphere of domestic politics, taking into account that a substantial number of these states have to deal with minorities and secessionist claims themselves. ${ }^{75}$ They were indeed quick to point out the dangers of a precedent-setting recognition of a breakaway region such as Kosovo for international and domestic stability. ${ }^{76}$

Several recognizing states acknowledged this danger and explicitly stressed the 'unique character' of Kosovo in their declarations of recognition, anxious to refute

7I Council of the European Union, Press Release of I8 February 2008 (regarding proceedings at the 2850th meeting on General Affairs (6946/08)), available at www.consilium.europa.eu/uedocs/ cms_data/docs/pressdata/en/gena/988I8.pdf.

72 See, e.g., Statement of the Republic of China (Taiwan) on Kosovo, I9 February 2008, available at www.mofa.gov.tw; see also Kingdom of the Netherlands, Nieuwsbericht: Nederland erkent onafhankelijkheid Kosovo, 4 March 2008, available at www.minbuza.nl.

73 Almqvist, supra note 4, at 8; see also, e.g., Statement of HE Mr Ali Babacan (minister of foreign affairs of the Republic of Turkey), 'Regarding the Recognition of Kosovo by Turkey', I8 February 2008, available at www.mfa.gov.tr.

74 See, e.g., Press Briefing of the Ministry of External Affairs of India in Response to Questions on Developments Regarding Kosovo, I 8 February 2008, available at http://meaindia.nic.in; see also, e.g., Press Release of the Ministry of Foreign Affairs of the Russian Federation, I 5 February 2008, available at www.mid.ru.

75 A. Cooley and H. Spruyt, Contracting States: Sovereign Transfers in International Relations (2009), 203.

76 Cf. Statement by Russian deputy minister of foreign affairs Alexander Grushko at the Opening of the OSCE Annual Security Review Conference, I July 2008, available at www.mid.ru: 'The unilateral declaration of Kosovo's independence came as a serious challenge, as it has created a dangerous precedent of going beyond the confines of the underlying principles of the Helsinki Final Act. Questions of territorial integrity of states and inviolability of borders have again taken center stage on the European agenda.' 
the claim that a dangerous precedent was being set. ${ }^{77}$ Obviously, this emphasis on the sui generis character of the recognition of Kosovo diminishes the international-law relevance of such a recognition.

In an awkward statement of I 8 February 2008, the Council of the European Union, for instance, stressed the fundamental importance of the international principles of sovereignty and territorial integrity, while at the same time arguing that these principles would not fully apply to the sui generis case of Kosovo:

The Council reiterates the EU's adherence to the principles of the UN Charter and the Helsinki Final Act, inter alia the principles of sovereignty and territorial integrity and all UN Security Council resolutions. It underlines its conviction that in view of the conflict of the Ig9os and the extended period of international administration under SCR I 244, Kosovo constitutes a sui generis case which does not call into question these principles and resolutions. ${ }^{78}$

The events in Kosovo made it painfully clear that the international community of states was seriously divided on the issue of state recognition and that international law played only a minor role in the process of recognition. This uneasy state of affairs would be emphasized again by the events in Georgia, only a few months later.

\subsection{South Ossetia and Abkhazia}

After a period of civil war in the early I990s, the republic of Georgia reached an uneasy coexistence with two of its ethnic regions, South Ossetia and Abkhazia, which had organized themselves as de facto autonomous entities, supported by Russia. ${ }^{79}$ Underlying tensions escalated in the summer of 2008, when Georgian troops launched an offensive against the South Ossetian capital, Tsinvali. Russia reacted immediately with a fierce counteroffensive, officially in response to the killing of Russian peacekeeping forces by Georgian troops. A second front was opened when Abkhazia, again with Russian support, joined the offensive and it did not take long before Georgia had to admit defeat and a peace agreement was concluded under international auspices. ${ }^{80}$

On 26 August 2008, a few weeks after the cessation of hostilities, Russia formally recognized South Ossetia and Abkhazia as independent states. ${ }^{8 \mathrm{I}}$ The formal declaration mainly refers to political motives, such as Georgian provocations and failed negotiations, but contains a legal line of reasoning as well:

77 Statement by Secretary of State Condoleezza Rice, 'U.S. Recognizes Kosovo as Independent State', I 8 February 2008, available at www.state.gov: 'The unusual combination of factors found in the Kosovo situation including the context of Yugoslavia's breakup, the history of ethnic cleansing and crimes against civilians in Kosovo, and the extended period of UN administration - are not found elsewhere and therefore make Kosovo a special case. Kosovo cannot be seen as a precedent for any other situation in the world today'; see also Canada, 'Canada Joins International Recognition of Kosovo', News Release, I 8 March 2008, available at www.international.gc.ca.

78 Council of the European Union, supra note $7 \mathrm{I}$.

79 V. Chetarian, War and Peace in the Caucasus: Ethnic Conflict and the New Geopolitics (2008), 373.

80 For a more detailed overview, see Independent International Fact-Finding Mission on the Conflict in Georgia, Report (30 September 2009), Vol. III, at I99-226, available at www.ceiig.ch/Report.html.

8I Statement by the Ministry of Foreign Affairs of the Russian Federation, 29 August 2008, available at www.mid.ru. 
Making this decision, Russia was guided by the provisions of the Charter of the United Nations, the Helsinki Final Act and other fundamental international instruments, including the 1970 Declaration on Principles of International Law concerning Friendly Relations among States. It should be noted that in accordance with the Declaration, every State has the duty to refrain from any forcible action which deprives peoples of their right to self-determination and freedom and independence, to adhere in their activities to the principle of equal rights and self-determination of peoples, and to possess a government representing the whole people belonging to the territory. There is no doubt that Mikhail Saakashvili's regime is far from meeting those high standards set by the international community. ${ }^{82}$

Once again, the right to self-determination was used in a non-colonial context and was seen as the basis for South Ossetia's and Abkhazia's remedial secession claims. The right to remedial secession - that is, a secession that derives its lawfulness from the illegitimate character of the governing regime - is arguably codified in the Friendly Relations Declaration, which, in the International Court of Justice's view, constitutes customary international law. ${ }^{83}$ This document, however, also stresses the principles of sovereignty and territorial integrity, ${ }^{84}$ which the non-recognizing states readily relied on to condemn Russia's recognition. ${ }^{85}$ This position was shared by NATO - an attitude that Russia regarded to be 'a politically motivated, selective interpretation of international law, based on double standards', in view of NATO's earlier involvement in Kosovo. ${ }^{86}$ At the same time, the double-standards criticism can apply with equal force to Russia, which recognized South Ossetia and Abkhazia, but not Kosovo. Ultimately, whether or not the circumstances of a given case warrant remedial secession and, in particular, whether or not a regime is legitimate and sufficiently protective of minority rights are in the eye of the beholder. ${ }^{87}$ Accordingly, the vagueness of the applicable legal standard serves all protagonists well to claim the moral high ground and, as the case may be, to vindicate or reject the lawfulness of the secession and their subsequent (non-)recognition.

As in the Kosovo crisis, legal discourse on the recognition of South Ossetia and Abkhazia could be reduced to playing off the right to self-determination against the

82 Statement by the Ministry of Foreign Affairs of the Russian Federation, 26 August 2008, available at www.mid.ru.

83 See Kosovo Advisory Opinion, para. 80; Military and Paramilitary Activities In and Against Nicaragua (Nicaragua v. United States of America), Judgment at the Merits Phase, [I986] ICJ Rep. I, at IOI-3, paras. I9I-I 93). Remedial secession is tackled in para. 5(7) of the Declaration on Principles of International Law Concerning Friendly Relations and Co-Operation among States in Accordance with the Charter of the United Nations, GA Res. 2625 (I970), Annex, 25 UN GAOR, Supp. (No. 28), UN Doc. A/52 I 7, at I 2 I, which provides that the principle of territorial integrity in a context of self-determination of peoples only applies to states 'conducting themselves in compliance with the principle of equal rights and self-determination of peoples as described above and thus possessed of a government representing the whole people belonging to the territory without distinction as to race, creed or colour.'

84 Ibid.: 'Nothing in the foregoing paragraphs shall be construed as authorizing or encouraging any action which would dismember or impair, totally or in part, the territorial integrity or political unity of sovereign and independent States.'

85 See Council of the European Union, 'Presentation of the Report of the Independent International FactFinding Mission on the Conflict in Georgia', Press Release I3875/09, 30 September 2009, available at www.consilium.europa.eu/uedocs/cms_data/docs/pressdata/en/er/I I0370.pdf.

86 R. Weitz, Global Security Watch - Russia: A Reference Handbook (2010), I 54.

87 For instance, in the preparatory works of its act of recognition, Russia aims to distinguish the situation of Kosovo from the situation of South Ossetia and Abkhazia for self-determination, independence, secession, and recognition purposes; cf. Chetarian, supra note 79, at 377. 
principle of territorial integrity. This account exposes once more the fundamental uncertainty on the role, content, and scope of the legal norms on state recognition. It should be noted, however, that the final report of the Independent International FactFinding Commission does contain a rather elaborate legal argumentation in which both traditional and post-Yugoslavian criteria are used to evaluate whether or not the entities should be recognized. ${ }^{88}$ Unfortunately, this nuanced legal discourse was not taken up by the community of states, much unlike the impact that the Badinter Commission had on the state and institutional discourse and practice during the dissolution of Yugoslavia. An important reason for this might be the fact that the report of the Fact-Finding Commission was only published almost a year after the events in Georgia took place.

\subsection{Conclusion}

Earlier in this article, it was established that legal doctrine was sharply divided as to the new normative framework on recognition after the events in Yugoslavia. This division was situated on three levels: the content and scope of the applicable norms, especially the right to self-determination; the relationship between the traditional framework and the new conditions developed during the Yugoslavia crisis; and the legal or political nature of the applicable normative framework. Recent state practice shows that the international state community currently finds itself confronted with the very same uncertainties.

On the conceptual level, state practice reveals a state of fundamental confusion as to the concrete content of the right to self-determination and its relation to the principle of territorial integrity, now that the former concept appears to have broadened in scope to include non-colonial contexts as well. The case studies of Kosovo, South Ossetia, and Abkhazia show that these concepts are played out against each other. There is no further elaboration on their respective content or mutual relation. This ultimately leads to a legal stalemate and allows political expediency to carry the day.

To what extent does the current discourse apply the traditional norms and the more modern criteria regarding human rights, democracy, and minority protection? As far as the traditional criteria are concerned, it is striking that the Montevideo requirements are almost entirely absent in the - limited - legal discourse of states. Nevertheless, even though the impact of the traditional criteria appears to be diminishing, it is probably a bridge too far to state that the traditional criteria have become entirely obsolete in the process of state recognition. After all, legal doctrine - and, for that matter, the Georgia Fact-Finding Commission - do remain faithful to the traditional criteria. ${ }^{89}$ As far as the modern criteria of human rights, democracy, and minority protection are concerned, it is noted that the Ahtisaari plan - a proposal launched during the Kosovar negotiations that was abandoned eventually - referred

88 Independent International Fact-Finding Mission on the Conflict in Georgia, Report (30 September 2009), Vol. II, at I 27-35, available at www.ceiig.ch/Report.html; in the report, it was concluded that neither South Ossetia nor Abkhazia should be recognized, due to the preconditions of statehood not being met, the unlawfulness of the secession, and the lack of minority and human-rights protection.

89 Cf. Vidmar, supra note 62, at 818; Independent International Fact-Finding Mission on the Conflict in Georgia, Report (30 September 2009), Vol. III, at I 27-35. 
to the need for Kosovo to respect human rights, develop democratic institutions, and protect minorities before it could be granted independence. ${ }^{90}$ Also, some official state declarations refer to human rights and minority protection..$^{9 \mathrm{I}}$

Indeed, recognition of secession sometimes hinges on the insufficient realization of the right to self-determination by a mother state. This remedial-secession discourse arguably undergirds Western recognition of Kosovo and Russian recognition of the Georgian breakaway regions. At the same time, this apparently legal discourse may serve as a Trojan Horse to reintroduce all sorts of political considerations into the recognition process.

This point brings us to the more fundamental question as to the extent to which state recognition is determined by political or legal factors. In the final analysis, the desired result informs various types of legal argumentation, based on the Montevideo criteria, human rights and democracy, territorial integrity, remedial secession, etc. As a result, international law seems to have become unable to fulfil its traditional role as an outer limit on state discretion..$^{2}$

In conclusion, it can be stated that the fog banks surrounding the process of state recognition, created during the dissolution of Yugoslavia, still remain. The lack of a clear-cut normative framework gives way to uncertainty and incoherent policies based on 'unique cases'. ${ }^{93}$ The case studies furthermore sharply reveal the potential threats of these inconsistencies for international stability, as Worster aptly states:

It may be that the widespread recognition of Kosovo has spurned a 'war of recognitions', the latest salvo of which is the movement within Russia to recognize the independence of South Ossetia and Abkhazia, a diplomatic attack on Georgia's territorial integrity. ${ }^{94}$

Bearing this in mind, it may seem to be regrettable that the International Court of Justice let slip a great opportunity to clear things up when it was asked to give an advisory opinion on the accordance of Kosovo's unilateral declaration of independence with international law. As already noted, instead of giving guidance on the content, scope, and status of the norms that govern the process of state recognition, the Court refused to touch upon the matter and limited itself to answering the narrowly framed question of whether the declaration of independence itself was lawful, irrespective of its consequences. That said, it is not unusual for the Court to live up to some judicial economy and to refuse to give answers to questions that are only implied in, or bear only an indirect relationship with, the question submitted to it.

90 Letter from the UN Secretary-General addressed to the President of the Security Council dated 26 March 2007, UN Doc. S/2007/I68 (2007).

9I See, e.g., Canada, 'Canada Joins International Recognition of Kosovo', News Release, i 8 March 2008, available at www.international.gc.ca; see also Kingdom of the Netherlands, supra note 72.

92 Cf. Almqvist, supra note 4, at 2.

93 B. Coppieters, 'The Recognition of Kosovo: Exceptional but Not Unique', in M Emerson (ed.), Readings in European Security: Volume 5 (2009), 97.

94 W. Worster, 'Law, Politics, and the Conception of the State in State Recognition Policy', (2009) 27 Boston U. ILJ I I 5 , at I I 7 . 


\section{QUO VADIS?}

Since the International Court of Justice has failed to shed more light on the uncertainties as to recognition described above, the final part of this article takes a closer look at those incertitudes in a careful attempt to answer some of the questions that have arisen over the last two decades. These questions are the following: (i) How can a balance be struck between the principle of territorial integrity and the right to (external) self-determination and what are, or should be, the consequences for the practice of recognition? (ii) How much morality can this process bear for the effectiveness of the legal system not to suffer? (iii) How can the law accommodate political expediency?

\section{I. Right to self-determination versus territorial integrity}

The scope of the right to self-determination was traditionally limited to colonial situations. During the dissolution of Yugoslavia, the right to self-determination was, however, extended to a clearly non-colonial context. ${ }^{95}$ Since it was evident that an unrestricted right to self-determination would soon lead to fragmentation and chaos, especially if it were given an external dimension (secession), the question arose as to the new limits of this right. ${ }^{96}$

One possible and promising approach to answering this question starts from the distinction between internal and external self-determination. Even though several definitions still exist, the internal dimension essentially encompasses the right to gain autonomy within the state, whereas the external dimension constitutes the right to organize oneself as a state - the right of secession. ${ }^{97}$ The internal right to selfdetermination, it is argued, should be seen as a universal right, and support for this statement is sought in the universal formulation of the right to self-determination in official documents such as UN Resolution I5I $4 .{ }^{98}$ The scope of the right to external self-determination needs to be construed more narrowly in light of its uneasy coexistence with the principle of territorial integrity. ${ }^{99}$ This right therefore only comes into being in exceptional situations. Frequently cited criteria in this regard are grave and repeated violations of human rights and the continuous negation of the right to internal self-determination. ${ }^{\text {I00 }}$ Secession then 'remedies' such violations. ${ }^{\text {Ior }}$

95 J. Castellino, International Law and Self-Determination (2000), I I8.

96 UN Secretary General, An Agenda for Peace: Preventive Diplomacy, Peacemaking and Peace-Keeping, UN Doc. A/47/277 - S/24I I I (I992), No. I7: 'Yet if every ethnic, religious or linguistic group claimed statehood, there would be no limit to fragmentation, and peace, security and economic well-being for all would become ever more difficult to achieve.'

97 A. Cassese, Self-Determination of Peoples: A Legal Reappraisal, International Law Commission, Hersch Lauterpacht Memorial Lectures (I995); K. Henrard, Devising an Adequate System of Minority Protection: Individual Human Rights, Minority Rights and the Right to Self-Determination (2000), 298; K. Knop, Diversity and Self-Determination in International Law (2002), I8.

98 Raic, supra note 3, at 287-8.

99 M. Shaw, International Law (2003), 444.

IoO Raic, supra note 3, at 328; L. Buchheit, Secession: The Legitimacy of Self-Determination (I 978), 94.

IOI See for the application of the remedial-secession discourse to the case of Kosovo and the argument that the criteria for its application are not satisfied in the case C. Ryngaert and C. Griffioen, 'The Relevance of the Right to Self-Determination in the Kosovo Matter', (2009) 8 Chinese Journal of International Law 573. 
The criteria of remedial secession are sometimes complemented by requirements of effectiveness, such as the territorial concentration of the affected people. ${ }^{\text {I02 }}$

It is certainly true that the distinction between internal and external selfdetermination is far from a new phenomenon. ${ }^{\text {I03 }}$ The true novelty lies in the fact that this distinction is gaining widespread attention as a way to redefine the right to self-determination in a manner compatible with the modern, post-colonial context. This is underlined by the fact that the theory is being put into practice as a framework to solve real-life cases, as shown by the oft-cited opinion of the Supreme Court of Canada in the Québec case. ${ }^{\text {I04 }}$

This adaptation by legal practice is an important step towards a renewed normative framework able to bring back a degree of consistency to state practice, since it may bar recognition of an entity that has seceded without a - clearly definable - right of external self-determination. De lege lata, as noted, such recognition is presumably not illegal, as a secession may not qualify as a violation of a peremptory norm, if a violation of an international legal norm at all.

Another point of attention is the principle of uti possidetis. This principle played an important role in the decolonization era: it was considered to be the only workable solution to protect the stability of administrative or colonial borders during the process of decolonization. ${ }^{\text {I05 }}$ Interestingly, it was used to evaluate the seceding territories during the crisis in Yugoslavia, which resulted in the recognition of the federal entities and the non-recognition of other entities such as the Republic of Serbian Krajina, even though these entities fulfilled all conditions for statehood. ${ }^{\text {106 }}$ By considering uti possidetis to be a general principle of international law, the Badinter Commission provided doctrinal support for this practice. ${ }^{\text {I07 }}$

The assumption that the principle of uti possidetis enjoys universal validity is, however, contested by some authors, who opine that the principle can only be considered to be normative in colonial contexts. ${ }^{108}$ In fact, all too strict an adherence

102 K. Henrard, Minority Protection in Post-Apartheid South Africa: Human Rights, Minority Rights and SelfDetermination (2002), 22.

I03 See, e.g., D. Nincic, The Problem of Sovereignty in the Charter and in the Practice of the United Nations (I 970), 248; M. Pomerance, Self-Determination in Law and Practice (I 982), 37.

I04 Canada Supreme Court, Reference Re Secession of Quebec, Judgment of 20 August I998, (I998) ILM I37I, at I 373 (emphasis in original): 'The recognized sources of international law establish that the right to selfdetermination of a people is normally fulfilled through internal self-determination - a people's pursuit of its political, economic, social and cultural development within the framework of an existing state. A right to external self-determination ... arises only in the most extreme of cases and, even then, under carefully defined circumstances.' The Court continues by distinguishing three situations in which the right to external self-determination comes into play: '[T]he international law right to self-determination only generates, at best, a right to external self-determination in situations of former colonies; where a people is oppressed, as for example under foreign military occupation; or where a definable group is denied meaningful access to government to pursue their political, economic, social and cultural development. In all three situations, the people in question are entitled to a right to external self-determination because they have been denied their ability to exert internally their right to self-determination.'

I05 Case Concerning the Frontier Dispute (Burkina Faso/Republic of Mali), Judgment of 22 December I986, [I986] IC] Rep. 567; Castellino, supra note 95, at I4I.

Io6 A. Bayefski (ed.), Self-Determination in International Law: Quebec and Lessons Learned (2000), I47; J. Preece, National Minorities and the European Nation-States System (I 998), 46.

I07 Badinter Commission, Opinion No. 3, I I January I992, (I992) 3 EJIL I, at I 85.

I08 S. Lalonde, Determining Boundaries in a Conflicted World: The Role of Uti Possidetis (2002), 202; T. Potier, Conflict in Nagorno-Karabakh, Abkhazia and South Ossetia: A Legal Appraisal (200I), 44. 
to the principle of inviolability of borders rules out negotiated solutions to territorial issues. This can ultimately undermine the chances of a peaceful outcome for a dispute. ${ }^{\text {I09 }}$ The use of uti possidetis outside colonial contexts furthermore seems to seriously disadvantage federal states, since federal sub-entities, as shown by the dissolution of Yugoslavia, seem to have a stronger claim to external self-determination. This appears to be particularly unfair, as it paradoxically 'punishes' federal states for having granted some form of federal autonomy to their ethnic or cultural regions. ${ }^{\text {Io }}$ The recognition of Kosovo suggests an even wider interpretation of uti possidetis to include all administrative borders (Kosovo being a province and not a federal entity of Serbia or the former Yugoslavia). That said, as Lalonde rightly observes, although uti possidetis is not, and should not be, binding custom that applies to all territorial disputes, it can represent a valid option or a guiding principle in resolving such disputes. ${ }^{\text {II I }}$

\subsection{Effectiveness versus morality}

The blurred relationship between the traditional Montevideo requirements and a new generation of criteria for recognition, such as respect for human rights, minority protection, and democracy, originates from the field of tension between statehood as a factual given and statehood as a moral engagement. The Montevideo requirements only deal with the presence or lack of certain attributes of statehood. In so doing, they ignore the entity's internal organization or the way those attributes have been acquired, save for a rather marginal check on whether or not such violations as apartheid or aggression have occurred in the process of state formation. In this view, statehood and recognition are, in essence, amoral. ${ }^{\text {II2 }}$ In contrast, the new criteria are predicated upon a value system; as such, they have a considerable moral dimension. ${ }^{\text {II } 3}$ The entry of this moral dimension into the process of state recognition may possibly be attributed to the rising influence of non-state actors and public opinion on state practice. ${ }^{\text {II } 4}$

The use of criteria with a significant moral dimension can be welcomed as an important correction to the amoral Montevideo requirements. ${ }^{\text {II5 }}$ This being said, it should be well understood that the Montevideo requirements should remain the basis of any normative framework on state recognition. After all, the principle of effectiveness (effectivitê) on which those criteria are based plays an abiding key role in the functioning of the decentralized international community of states. ${ }^{\text {II }}{ }^{\text {Entities }}$

I09 M. Fabry, Recognizing States: International Society and the Establishment of New States since I776 (2010), 206; Radan, supra note 43 , at 232.

i Io R. Mullerson, 'Introduction', in R. Mullerson, M. Fitzmaurice, and M. Andenas (eds.), Constitutional Reform and International Law in Central and Eastern Europe (I998), xx.

I I Lalonde, supra note io8, at 240.

I 2 Rich, supra note 2 , at 64 .

I 3 Chinkin, supra note 64, at I06-7 (as to human rights); Wouters, De Meester, and Ryngaert, supra note 42, at I58 (as to democracy).

I 4 Hammer, supra note 28, at 3I; Sloane, supra note I, at I I4.

I 5 Rich, supra note 2 , at 64 .

I 6 Cf. Kreijen, supra note 20, at I3: 'Because centralized coercion and compulsory adjudication are essentially lacking in the international legal order, this order must almost entirely rely on the factual ability of its subjects to provide the implementation and enforcement of its norms. To put it another way, to endow 
that are unable to assume the rights and duties that come with statehood cannot be admitted to the international community. ${ }^{\text {II }}$

The principle of effectiveness therefore constitutes a vital threshold. That being said, it should be noted that the fulfilment of moral criteria, most notably the presence of democratic institutions, adds to the effectiveness of a new entity and thus strengthens this entity's position as being 'recognizable'. ${ }^{\text {II } 8}$ Moral criteria can therefore be seen as useful value-oriented corrections to the inherently amoral core principle of effectiveness and, at the same time, as a successful means to foster that very same effectiveness.

Nevertheless, some caveats should be kept in mind when applying moral criteria. First, some consideration should be given to the fact that a considerable number of generally recognized states do not meet some or all of the second-generation criteria. In theory, one could argue that, for this reason, the recognition of those existing states should be withdrawn. ${ }^{\text {II } 9}$ However, such a conclusion seems a bit hasty. In the interest of international stability, it is desirable that a high threshold is set before a state loses its statehood - witness cases such as Sudan and Somalia, entities still recognized as states notwithstanding their continuing lack of effective governments. ${ }^{\mathrm{I} 20}$ Moreover, imposing such criteria as human-rights protection or democratic institutions on existing states would probably be perceived as a flagrant violation of the well-established prohibition of intervention in internal affairs. ${ }^{\text {II }}$

For an existing state, this hardly rebuttable 'presumption of statehood' entails that when it does not meet some of the criteria, whether of the first or the second generation, such does not bring about an end to its statehood. ${ }^{\text {I22 }}$ Incidentally, it means that higher standards are used for new states than for existing states. This being so, an existing state's meeting the moral criteria plays an important part in occupying the moral high ground when recognizing another entity; this may increase the credibility and leverage of the recognizing state.

Second, and more fundamentally, the use of moral criteria increases the risk of inconsistency in the process of state recognition: after all, such criteria lack a clear and unambiguous definition. ${ }^{\text {I23 }}$ The way the criteria were put into practice during the dissolution of Yugoslavia indeed shows their potential for arbitrariness, ${ }^{\mathrm{I} 24}$ as does the application of too-loosely defined criteria for remedial secession. In this respect, we should remind ourselves of Lauterpacht's warning so many years ago:

entities, which do not possess the factual ability to act in accordance with the normative requirements of a decentralized legal order - i.e., to confer on them the legal capacity to be the bearers of rights and duties under the order, while merely presuming their factual capacity - is to put at risk the functioning of that order.'

I 7 C. Hillgruber, 'The Admission of New States to the International Community', (I998) 9 EJIL 49I, at 499.

i 8 J. d'Aspremont, 'Post-Conflict Administration as Democracy-Building Instruments', (2008) i I 8 Chicago JIL I, at I5.

I I 9 Dugard, supra note 53 , at 89 .

I20 Raic, supra note 3, at 7I; d'Aspremont, supra note 25, at 663; Shaw, supra note 99, at I 86.

I2 I Hillgruber, supra note i I7, at 50I.

I 22 K. Buhler, State Succession and Membership in International Organizations: Legal Theories versus Political Pragmatism (200I), I8; Kreijen, supra note 20, at 24.

I23 Rich, supra note 2, at 64 .

I24 Dugard, supra note 53, at 89-9o. 
Once considerations of that [moral] nature are introduced as a condition of recognition, the clear path of law is abandoned and the door wide open to arbitrariness, to attempts at extortion and to intervention, at the very threshold of statehood. ${ }^{125}$

It is therefore necessary to define these moral criteria as far as possible, while leaving room for taking into account the situation in the field and the entity that may be in need of recognition. Evidently, compliance with these criteria must be closely monitored during the evaluation period, and no recognition can occur when the criteria are not met. The duration of this evaluation period should be well defined and reasonable. Otherwise, an entity claiming statehood would find itself in legal purgatory for too long, which could negatively affect international stability. ${ }^{\text {I26 }}$ Finally, as far as remedial secession is concerned, states may want to clarify the precise circumstances under which they would lose a moral right to portions of their territory: at what point can they be considered to insufficiently protect a people's right to internal self-determination and at what point can other states recognize a territorial entity that has seceded on moral grounds?

\subsection{Law versus politics}

State recognition is a process in which the spheres of law and politics are closely intertwined. One major reason for this is the key role recognition plays in the Westphalian state system: as the system lacks a central authority, an entity can only fully enter it by explicit or tacit consent of other system participants: states. ${ }^{\text {I27 }}$ This means that states play a dual role in the international legal system: they protect their own interests and act as gatekeepers of the system. A fundamental tension thus ensues between recognition as a legal act allowing an entity entry into the community of states and recognition as a political act advancing the interests of the recognizing state. ${ }^{\mathrm{I} 28}$

In this context, it is not desirable, even from a state perspective, that the process of state recognition should belong in its entirety to the realm of political discretion and thus subjective appreciation. ${ }^{\mathrm{I} 29}$ The importance of the principle of effectiveness, and of the attendant objective criteria for statehood derived from the Montevideo Convention, for the functioning of the decentralized international community has already been pointed out. Complementary moral criteria, for their part, may feed into the legal system and thereby increase the legitimacy of the process vis-à-vis public opinion. ${ }^{\mathrm{I} O}{ }^{2}$ Legal norms furthermore reduce the complexity of the choices with which states are confronted, thus further adding to international stability. ${ }^{\mathrm{I3I}}$

I25 Lauterpacht, supra note 28, at 316.

I26 D’Aspremont, supra note 25, at 662.

I 27 Caplan, supra note 22, at 85; S. Halperin, War and Social Change in Modern Europe: The Great Transformation Revisited (2004), 30.

I 28 Lauterpacht, supra note 28 , at 320; Hammer, supra note 28 , at 3 I.

I29 Lauterpacht, supra note 28 , at 322 : 'There are obvious advantages in relating the fundamental features of international relations - and the rise of new States is one of them - to an objective rule of law rather than to the shifting arbitrariness of national expediency.'

I30 Even though some authors seem to differ, these moral criteria are legal norms nevertheless. Their discretionary nature follows not from their moral dimension, but from the uncertainty that still exists as to their content.

I3 I Caplan, supra note 22, at 9. 
The cases of Kosovo and Georgia have indeed shown the consequences of normative uncertainty for international relations.

\subsection{Conclusion}

This article started from the distorted relationship between law and politics in the process of state recognition and the way this was reflected in recent state practice. It was stated that the dissolution of Yugoslavia marked the beginning of a fundamental evolution in the normative framework governing recognition, giving way to uncertainty and incoherence that, in turn, led to increased political tension. A new coherent normative framework, leaving enough room for political considerations while avoiding arbitrariness, is still in the process of being shaped.

If the state community is to accept a new normative framework regulating the process of state recognition to a minimal yet necessary extent - as indeed it should there must first be a consensus on the content and scope of the norms making up this framework. ${ }^{132}$ The uncertainties that have arisen during the last few decades are closely intertwined: the balance between law and politics in the process of state recognition has been distorted by the confusion about the nature and content of the post-Yugoslavian normative framework. This balance can therefore only be restored when the clouds surrounding these new norms have finally disappeared.

This being said, one should bear in mind that, despite efforts from scholars, judges, and diplomats, the issue of state recognition remains - and will remain - a much-debated issue. This article only aspires to offer one possible approach, keeping in mind the modest wisdom of Kelsen: 'The problem of recognition of states and governments has neither in theory nor in practice been solved satisfactorily. Hardly any other question is more controversial, or leads in the practice of states to such paradoxical situations.' ${ }^{\text {I33 }}$

I32 Worster, supra note 94, at I6I.

I33 H. Kelsen, 'Recognition in International Law: Theoretical Observations', (I94I) 35 AJIL 605, at 605. 